\title{
LAS SANCIONES ADMINISTRATIVAS $Y$ LA DESPENALIZACION DE FALTAS CONTRA EL REGIMEN DE LAS POBLACIONES
}

\author{
POR \\ LEOPOLDO TOLIVAR ALAS
}

\begin{abstract}
SUMARIO: I. INTRODUCCIÓN.-II. APARICIÓN Y EVOLUCIÓN HISTÓRICA DE LAS FALTAS CONTRA EL RÉGIMEN DE LAS POBLACIONES.-III. FALTAS ADMINISTRATIVAS Y PENALES: LA OCASIÓN PERDIDA EN LA REFORMA DE 1989: 1. Los criterios de la exposición de motivos. 2. Supuestos despenalizados y tipos mantenidos.-IV. APELACIÓN A UN CAMBIO REAL E INAPLAZABLE.
\end{abstract}

\section{INTRODUCCION}

Uno de los problemas más señalados por la doctrina a la hora de estudiar la potestad sancionadora de la Administración es la existencia de zonas borrosas en las que las facultades gubernativas de corrección se confunden con las medidas judiciales a adoptar contra los ilícitos penales (1).

La Constitución española de 1978 ha optado, como es bien sabido y no menos discutible, por la perpetuación del poder sancionador de los entes públicos, manteniendo su configuración de potestad en sentido técnico, en tanto que facultad conferida a la Administración directamente por el ordenamiento y no en virtud de una relación jurídica (2).

En efecto, el artículo 25.3 de la norma fundamental ha defendido

(1) Vid., por todos, PARADa VÁzQUEZ, J. R.: «El Poder sancionador de la Administración y la crisis del sistema judicial penal», en Revista de Administración Pública núm. 67, 1972, especialmente pp. 66 y ss. Más recientemente, el mismo autor, en el capitulo XI de su Derecho Administrativo I. Parte general (Marcial Pons, Madrid, 1989), ha abordado "La actividad sancionadora» a la luz de las nuevas referencias constitucionales, en un estudio de extraordinario interés. Sobre la potestad sancionadora de la Administración pueden consultarse, entre otras aportaciones, SANZ GANDASEGUI, F.: La potestad sancionadora de la Administración: La Constitución española y el Tribunal Constitucional, Edersa, Madrid, 1985; MARTíN-RETORTILLO. L.: Las sanciones de orden público en el Derecho español, Tecnos, Madrid, 1973; GARCíA DE ENTERRÍA, E.: «La incidencia de la Constitución sobre la potestad sancionadora de la Administración», en Revista Española de Derecho Administrativo núm. 29, 1981, pp. 359 y ss.; ESTEVE PARDO, J.: «Sanciones administrativas y potestad reglamentaria», REDA núm. 49, 1986, pp. 99 y ss. (se comenta la sentencia del Tribunal Supremo de 28 de enero de 1986); SUAY RINCón. J.: «EI Derecho Administrativo sancionador: perspectivas de reforma», RAP núm. 109, 1986. pp. 185 y ss. Tanto en este último trabajo como en la monografía citada de SANZ GANDASEGUI se aborda la necesidad de un tratamiento legislativo global para las diversas sanciones administrativas, hasta la fecha dispersas por los más diversos recovecos del ordenamiento.

(2) Cfr. Garcia de Enterría, E., y Fernández, T. R.: Curso de Derecho administrativo, 1, Civitas, Madrid, 1983, pp. 418 y ss. 
la existencia de las sanciones administrativas con la única cautela -y sólo para la Administración civil (3)- de que no conlleven, ni directa ni subsidiariamente, la privación de libertad.

Las sanciones administrativas suelen hallarse conexas, como respaldo conminatorio, a otras potestades como la tributaria, la planificadora, la de organización, la expropiatoria o la más general que otorga a los sujetos públicos la facultad de expresarse a través de actos administrativos. Los ilícitos administrativos reciben en la incodificable legislación de esta naturaleza diversas denominaciones más o menos genéricas como «infracciones» (4) o "faltas» que a su vez admiten, según la norma de cada sector, diversas modulaciones en función de la gravedad. La tipicidad de las conductas castigables -tanto en lo que respecta a los administrados sometidos a sujeción general como a los especialmente vinculados a los servicios públicos- se encuentra desparramada, también, por muy diversas leyes y, en cualquier caso, normas con este rango han de ser las que prevean la irregularidad de los comportamientos recriminables desde la Administración como con nitidez ha manifestado el Tribunal Constitucional (5). En fin, la sanción en que suele concretarse la condena administrativa puede consistir en una «multa» (supuesto harto frecuente) o en una «privación de derecho no pecuniario» (6).

Por cuanto esquemáticamente acabamos de señalar, no resulta extraño que sea razonable pensar, sin partimos de la premisa de la

(3) Como es sabido, el Tribunal Constitucional ha ratificado esta singularidad de la Administración militar para imponer "arrestos» y demás sanciones privativas de libertad, al reconocer indirectamente la especial configuración de dicha potestad sancionadora castrense en su sentencia de 15 de junio de 1981.

(4) De «infracciones» habla el artículo 25.1 de la Constitución y diversas leyes posconstitucionales, como la de Costas, de 28 de julio de 1988 (art. 90), o la General de Sanidad, de 25 de abril de 1986 (art. 32). El término "faltas» lo emplean, por ejemplo, la Ley de Bases de Régimen Local de 2 de abril de 1985, en su artículo 21.1.k) o la Ley de Medidas de Reforma de la Función Pública de 2 de agosto de 1984 (art. 31).

(5) La doctrina del Tribunal Constitucional, que examinaremos con más detalle en las siguientes páginas, parte de una leve mitigación del rigor de la reserva de la Ley formal establecida en el artículo 25.1 de la Constitución en lo tocante a las infracciones administrativas. Ello porque, en el ámbito de la Administración, no puede prescindirse del papel regulador del reglamento. Esa atenuación cobra su mayor importancia en las sanciones propias de las relaciones de sujeción especial. Pero, en todo caso, tanto por la vinculación positiva de la Administración a la ley, como por el imperativo constitucional, la expresión «legislación vigente» (que, por cierto, la norma fundamental aplica a delitos, faltas e infracciones administrativas por un igual), no puede dejar sin la debida «cobertura» a la actuación administrativa. Ello significa que la tipificación de conductas, los criterios sancionadores y los topes de las sanciones deben quedar en manos de una Ley. previa (entre otras, véanse las sentencias constitucionales 42/1987, de 7 de abril; 29/1989, de 6 de febrero, y 69/1989, de 20 de abril).

(6) Esta distinción, conexa con un buen número de casos a la diferencia entre sujeción general y especial, supone que, a las personas en este segundo status, la Administración puede inhabilitarlas, suspenderlas o expulsarlas. Pero también en las relaciones generales son posibles otras medidas, consistentes en obligaciones de no hacer o limitativas de derechos no económicos. Cfr. PARAdA VÁZQUEZ: Derecho Administrativo... cit., pp. 357 y ss. 
descoordinación legislativa, en la amenaza del bis in idem (7). Al cabo, no son escasos los bienes jurídicos similarmente protegidos por la justicia penal y por los entes públicos; la denominación de "faltas» es igual y originariamente común y también lo es, en muchos casos, la poena de carácter pecuniario.

Si no es difícil contemplar actualmente conductas socialmente detestables en las que, bien de lege data, bien de discusión doctrinal, un trasvase del campo de lo administrativo al criminal aparece justificado (tal ocurre en temas como el urbanismo, la caza, la protección monumental o ambiental...), existen otro tipo de actos de más dudosa incardinación, que tradicionalmente se han visto tipificados a caballo entre las dos ramas jurídicas mencionadas. Entre estos últimos comportamientos nos encontramos con las faltas que el Código punitivo ha venido llamando "contra los intereses generales y régimen de las poblaciones" y cuya incidencia en el campo administrativo y muy singularmente en la vida local resulta palmaria. Si en el primer tipo de conductas que hemos citado todo cambio represor tiende a actualizar la reacción contra acciones novedosas o que se han vuelto particularmente más peligrosas para los intereses y valores sociales, en el segundo tipo de actitudes las revisiones legales deben ir encaminadas a dejar en manos de la Administración lo que son meras medidas policiales, una vez que se ha optado, desde la propia Constitución, por el mantenimiento de la potestad sancionadora de los entes públicos.

En el sentido último, resulta particularmente oportuna la reforma introducida en el Código Penal por la Ley orgánica 3/1989, de 21 de junio, sin perjuicio de que, posiblemente, el acierto del legislador sólo pueda calificarse de parcial.

A las faltas contra el régimen de poblaciones y a su reciente modificación, dedicaremos nuestra atención en las siguientes líneas.

\section{APARICION Y EVOLUCION HISTORICA DE LAS FALTAS CONTRA EL REGIMEN DE LAS POBLACIONES}

La materia que ocupa nuestro interés en este trabajo es partícipe de dos clases de incongruencias que a lo largo de las siguientes

(7) Una reciente reflexión sobre la duplicidad sancionatoria podemos hallarla en el interesante estudio de QUINTANA LÓPEZ, T.: «EI principio non bis in idem y la responsabilidad administrativa de los funcionarios», en REDA núm 52, 1986, pp. 585 y ss. Pese al título del trabajo (en el que se halla una aguda crítica del articulo 23 del Reglamento Disciplinario de los funcionarios de 10 de enero de 1986), el autor se extiende a otros campos como la Ley de Aguas de 2 de agosto de 1985 o la del Patrimonio Histórico Español de 25 de junio de 1985 , donde también se aborda la diferencia y posibles colisiones entre delitos e infracciones administrativas (arts. 112 y 75.1 , respectivamente) 
líneas iremos examinando indistintamente. De un lado, las propias de los diversos sedimentos con que se ha formado nuestro actual Código Penal, con sus consecuentes incoherencias sistemáticas. De otra parte la ya antigua confusión de límites entre infracciones penales $y$ administrativas. Pero comencemos por examinar los orígenes y transformaciones de las faltas contra los intereses locales.

Nuestro vigente Código Penal aún es, como se sabe, sustantivamente heredero del dictado, en pleno período revolucionario, el 30 de agosto de 1870 . Por ello no debe extrañarnos que la configuración de las faltas $y$, muy singularmente, la rúbrica "contra los intereses generales y régimen de las poblaciones», provengan del citado cuerpo legal. Naturalmente, algunos de los comportamientos tipificados como faltas de este género por el Código de 1870 ya traían causa -e incluso idéntica redacción- del texto moderado de 19 de marzo de 1848. En este último no existe otra distinción para las faltas que la establecida entre las graves y las menos graves (8), pero sí podemos apreciar en él figuras que luego se encasillarán como peculiares del «régimen de poblaciones». Tal es el caso de los daños irrogados a objetos de utilidad o servicio público (9), la desobediencia de los reglamentos sanitarios en cuestiones epidemiológicas de higiene animal y humana o la infracción de normas sobre edificios ruinosos o actividades peligrosas (10), que se encuadrarán en el Código de 1848 como faltas graves, al igual que la contravención de la policía de espectáculos o de la prostitución (11). Todas estas acciones u omisiones tipificadas se refieren, como es notorio, a materias sustantivamente administrativas que el Código recoge en algunos casos por seguir precedentes legislativos, en otros supuestos por el convencimiento de la necesaria configuración criminal y, sobremanera, porque hasta esa época no empieza a apreciarse con nitidez la independencia del

(8) Libro tercero del Código Penal de 19 de marzo de 1848, que distingue entre las faltas graves (título I) y menos graves (título II). Las que afectan al sosiego de las poblaciones están incluidas, entre otras muchas, dentro de las graves (arts. 471 y 472), y su pena oscilaba entre cinco y quince duros. Sobre la historia de las faltas vid. TERUEL CARRALERO. D.: Las faltas (Doctrina. Comentario de las del libro tercero del Código Penal. Las formuladas en Leyes Especiales). Boch, Barcelona, 1956.

(9) El artículo 471 del CP de 1848 incriminaba, en su número 3, a «los que apedrearen, mancharen o deterioraren estatuas, pinturas $u$ otros monumentos de ornato o de utilidad pública, aunque pertenezcan a particulares». La redacción se ha mantenido prácticamente intacta hasta nuestros dias, aunque se hallan incorporado conductas que el texto de 1848 preveía en el punto siguiente como «daño que no exceda de cinco duros en paseos, parques, arbolados $u$ otros sitios de recreo o esparcimiento de las poblaciones o en objetos de pública utilidad").

(10) Artículos 471 (números 7 y 8) y 472 (números 1, 2 y 10) del CP de 1848 .

(11) Los desórdenes del espectáculo o de los que asistian a los espectáculos se recogían en los números 3 y 4 del artículo 472 del CP de 1848. que, en el número 9 del precepto anterior al citado advertía a «los que infringieren los reglamentos de policía en lo concerniente a mujeres públicas». 
poder sancionador administrativo (12). Será un Real Decretosentencia de 31 de octubre de 1846 el que reconozca por primera vez con claridad la mencionada potestad administrativa. Tras dicho pronunciamiento del Consejo de Estado, rigiendo ya el Código Penal de 1850, se expedirá el Real Decreto de 18 de mayo de 1853 que declaraba qué faltas podian reprimirse gubernativamente $y$ cuáles eran privativas de los Tribunales (13). El artículo 505 del

(12) Cfr. Parada VÁzouez: Derecho Administrativo..., cit., p. 338.

(13) Este importantísimo Real Decreto de 18 de mayo de 1853 fue publicado en la "Gaceta de Madrid" diez días más tarde. Por su trascendencia y escasa difusión transcribimos su contenido del periódico oficial:

"Ministerio de la Gobernación. Real Decreto. Enterada de lo que Me han manifestado Mis Ministros de la Gobernación y de Gracia y Justicia sobre las dudas y conflictos que ocurren frecuentemente entre la Administración y los Tribunales ordinarios por no determinar las leyes con la claridad debida cuándo pueden las Autoridades administrativas proceder gubernativamente en el castigo de las faltas, y cuándo deben hacerlo sujetándose a las formas del juicio; Considerando que es indispensable poner en armonía interinamente, y hasta la reforma definitiva del Código Penal, las disposiciones legales que mandan castigar las faltas con ciertas penas y previo juicio, con las leyes administrativas, y ordenanzas y reglamentos municipales que permiten corregir las mismas faltas gubernativamente y con penas distintas; Considerando que no debe quedar al arbitrio absoluto de los agentes administrativos la opción entre aquellos dos modos diversos de proceder, y el prescindir o no de las formas tutelares de la justicia; Considerando que la Administración desempeñaría mal o muy difícilmente sus atribuciones de vigilancia y tutela de los intereses públicos si careciese de los medios necesarios para dar a su acción toda la rapidez que en muchos casos requiere su eficacia; Considerando que si bien sería de desear que toda corrección, por leve que fuese, se impusiera en virtud de un juicio, no se puede aplicar este principio de una manera absoluta sin embarazar en muchos casos el curso de la Administración, y sin exponer el orden y los intereses públicos a graves peligros; Considerando que la amplitud que necesitan las autoridades municipales en su modo de proceder no exige sin embargo la facultad de imponer penas corporales sin juicio previo, a lo cual se opone por otra parte el artículo $7 .^{\circ}$ de la Constitución (de 1845). He tenido a bien dictar, de acuerdo con el parecer de Mi Consejo de Minsitros, y a propuesta de los de Gobernación y Gracia y Justicia, las disposiciones siguientes

Primera. Las faltas que según el Código Penal o las ordenanzas y reglamentos administrativos, merezcan pena de arresto, deberán ser castigadas siempre en juicio verbal, con arreglo a lo dispuesto en la ley para la ejecución de dicho Código

Segunda. Las faltas cuyas penas sean multa, o represión y multa, podrán ser castigadas gubernativamente a juicio de la Autoridad administrativa a quien esté encomendada la represión.

Tercera. Los Alcaldes de los pueblos conservarán la facultad gubernativa de imponer multas hasta en la cantidad que permite el artículo 75 de la Ley de 8 de enero de 1845 , y sin atenerse al límite señalado en el párrafo primero, artículo 505 del Código Penal, solamente cuando dichas penas estén establecidas en ordenanzas o reglamentos municipales vigentes, cuya publicación sea anterior a la del referido Código.

Cuarta. Los mismos Alcaldes podrán sin embargo imponer gubernativamente la pena de arresto por sustitución y apremio de la multa, con sujeción a lo dispuesto en el artículo 504 del Código Penal sólo cuando los multados fueren insolventes, y no pudiendo en ningún caso exceder de quince dias el tiempo de arresto.

Quinta. Las reglas anteriores no excluyen ni limitan por ahora las atribuciones que corresponden a los Gobernadores de las provincias para corregir gubernativamente ciertas faltas, con arreglo a lo dispuesto en la Ley de 2 de abril de 1845 .

Sexta. Los Gobernadores y los Alcaldes. llevarán en papel de oficio un libro foliado y rubricado en todas sus hojas, en el que asentarán por orden numérico todas las providencias gubernativas que dicten sobre faltas. En estas providencias se hará mención precisamente del nombre y domicilio del penado, de la falta cometida y de la pena impuesta. Estos asientos serán 
Código de 1850 (que reproducía en parte el artículo 493 del texto de 1848) reconoció, delimitándolo, el poder de las autoridades gubernativas para reprimir abusos o infracciones siempre que las sanciones no fueran superiores a las establecidas por el Código Penal (o existiesen leyes especiales autorizatorias) y a condición de que por ley o reglamento dictado al amparo de ésta se señalase la extensión o cuantía de la sanción. Dicho precepto será el embrión del artículo 625 del Código punitivo de 1870 y que hoy reproduce el 603 del texto en vigor.

Ese artículo 625 del Código de 1870 representa justamente una excepción (al igual que la Ley Municipal del mismo año) a la corriente contraria al reconocimiento de facultades sancionatorias a la Administración, que se inició tras la Revolución de septiembre de 1868. Como ha señalado PARADA VAZOUEZ el radicalismo democrático de la época conllevará «la potenciación máxima del poder judicial» en normas como el Decreto de Unificación de Fueros, la que suprimió la jurisdicción contenciosa en el Consejo de Estado, la propia Constitución de 1869 y la Ley de Orden Público de 1870 (14). Dentro de los seis años del período revolucionario

firmados respectivamente por el Gobernador o el Alcalde, y por el Secretario del Gobierno o del Ayuntamiento en su caso.

Séptima. De toda providencia gubernativa sobre faltas se dará al interesado una copia autorizada por el respectivo Secretario, en la cual se expresará el número y folio del libro en que se halle el original.

Octava. El Gobernador o el Alcalde que omitiere el asiento de que trata el artículo $6 .^{\circ} \mathrm{o}$ negare o dilatare la entrega de la copia de que habla el artículo anterior, incurrirá en responsabilidad, que le podrá ser exigida a instancia de parte o de oficio por el superior gerárquico inmediato. Dado en Aranjuez a diez y ocho de Mayo de mil ochocientos cincuenta y tres.-ESTÁ RUBRICADO DE LA REAL MANO.-EI Ministro de la Gobernación, PEDRO DE EGAÑA.»

Esta singular disposición administrativa de carácter provisional incide en cuestiones tan importantes como las penas corporales, la prohibición, en general, de arrestos administrativos y la regulación excepcional de éstos con carácter de sustitución y apremio de la multa. Por otra parte, el celo impuesto a Alcaldes y Gobernadores para inscribir las penas y dar copia al interesado de tal inscripción, parece apuntar la existencia de un documento liberador, inmune a una segunda causa por la misma falta. No obstante, la posibilidad del bis in idem, en materias no reservadas a los Tribunales, queda latente en el Real Decreto.

(14) Cfr. PARADA VÁZOUEZ: “El poder sancionador de la Administración...», cit., pp. 66 y ss. Con este autor también debemos recordar brevemente cómo las contradicciones entre el judicialismo a ultranza y la existencia de sanciones administrativas arranca ya de la propia Constitución de Cádiz que, a la vez, que reservaba el Poder Judicial y prohibía al Rey juzgar y hacer ejecutar lo juzgado (artículos 242 a 248), configuraba al Alcalde como el último eslabón de la cadena judicial, a la par que autoridad gubernativa (artículo 275 del texto de 1812). Un Decreto Constitucional de 23 de junio de 1813 confirió a los Jefes políticos la facultad de multar a los perturbadores del "orden o el sosiego público». PARADA VÁZQUEZ destaca que estas sanciones -con arresto sustitutorio-pasarán pronto a la legislación local y de orden público. El Código Penal de 1822, cuya efimera suerte hace pensar a parte de la doctrina que no llegó a tener vigor efectivo, señalaba en su articulo 185 (parodia del 486 francés) que ulas culpas y delitos no comprendidos en este Código que se cometan contra los reglamentos y ordenanzas particulares que rigen en algunos ramos de la Administración pública serán juzgados y castigados respectivamente con arreglo a las mismas ordenanzas y reglamentos». El espíritu doceñista parece intuir ya, ante tan clara atribución gubernativa, la ejecución de Riego y la venida 
aún, con los vientos republicanos, se intentaría una radical supresión de las sanciones gubernativas en el artículo 72 del Proyecto de Constitución F́ederal de 1873 (15).

El Código Penal de 1870 es, pues, un cuerpo contradictorio con el pensamiento jurídico-político de su tiempo $y$, también, guarda contradicciones en sí mismo. Si el reiterado artículo 625 parte de la coexistencia de sanciones penales y administrativas, su libro $3 .^{\circ}$, título II, al prescribir el régimen «de las faltas contra los intereses generales y régimen de las poblaciones» se decanta por un judicialismo a ultranza, ya que, tras esta novedosa rúbrica que ha llegado hasta nosotros, se encuentra un elevadísimo número de comportamientos ligados al giro administrativo.

La misma expresión uintereses generales y régimen de las poblaciones» es, aunque desafortunada técnicamente, sumamente expresiva. Los intereses generales a los que parece aludir son los de la población (así en los casos de alteración por rumores del precio de las cosas) ya que cualquier tipo penal perseguible de oficio se entiende que puede atentar contra los intereses generales. $Y$ en cuanto al régimen de las poblaciones está claro que este término equivale a lo que con más propiedad deben llamarse municipios. No olvidemos que, diecinueve años más tarde, el Código Civil aún utilizaría la expresión «pueblos» para referirse a los entes locales básicos (arts. 343, 344, 1875...).

\footnotetext{
de una «década ominosa». Tras el silencio de la Constitución progresista de 1837, habrá que esperar al gran período moderado para encontrar textos tan significativos como el Decreto de 18 de mayo de 1853 (transcrito en la nota anterior) o sus importantes precedentes delimitadores entre lo penal y lo administrativo, tales como el artículo 493 del Código Penal de 1848 (resumido en el texto) o el Decreto-Sentencia del Consejo de Estado de 31 de octubre de 1846 que no sólo señala que «la actividad de la Administración debe ser libre y desembarazada sin perjuicio de la responsabilidad de sus agentes" sino que proscribe los recursos judiciales contra las sanciones administrativas, pues ello presupondría "grave daño del servicio público y menoscabo de la independencia e irresponsabilidad de la Administración consignadas en la Constitución y en las Leyes».

Dictado el Código Penal de 1870, al que dedicamos especial atención en el texto, habrá que esperar a la I República para hallar una tentativa supresora de la potestad gubernativa de sanción. La Restauración, en general, confiará el castigo de los delitos y faltas extracodificados a los jueces ordinarios, dejando sólo facultades sectoriales de sanción a las Administraciones, casi siempre limitadas por razón de la cuantía. Tras la Dictadura de Primo de Rivera en la que la discrecionalidad para imponer sanciones administrativas no tuvo más límite, como transcribe PARADA VÁZOUEZ del Decreto-ley de 18 de mayo de 1926, "que el que señalen las circunstancias y el bien del pais y le inspire (al Gobierno) su rectitud y patriotismo", la II República no supuso freno notable a tal potestad administrativa, a salvo el régimen de garantías del que tampoco puede decirse que fuera el adecuado a un Estado de Derecho.

(15) El artículo 72 del Proyecto de Constitución Federal de la Primera República se refería al Poder Ejecutivo y se ubicaba en el título IX de la norma fundamental. Pero, entre este precepto y el 73, y dentro ya del título $X$ (Del Poder Judicial), aparecía una disposición sin ordinal alguno en cuyo parágrafo $2 .^{\circ}$ se dice que "Queda prohibido al Poder ejecutivo, en todos sus grados, imponer penas, ni personales ni pecuniarias, por mínimas que sean. Todo castigo se impondrá por el Poder judicial». La anécdota reseñada de este precepto sin numerar (que deberiamos llamar 72 bis) es bien conocida entre la doctrina constitucionalista.
} 
Entre las conductas atentatorias contra el régimen de poblaciones, recogía el Código de 1870 diversas acciones u omisiones que, por su utilidad como precedente legal, resumiremos bajo otra sistemática más acorde con el interés protegido. En esta suma de comportamientos. toscamente aglutinados bajo la rúbrica «régimen de las poblaciones", podemos distinguir:

Faltas contra la disciplina de mercado (alteración por rumores del precio de las cosas; infracción de reglas sobre abastecimiento de poblaciones; pesas y medidas fraudulentas y cantidades defraudadas en el peso) (16).

Faltas contra la policía de seguridad (dueños de fondas y locales de hostelería que no faciliten a la autoridad datos sobre la clientela y tenedores de animales feroces $y$ dañinos que infringen reglamentos creando situaciones de riesgo, así como guardadores de locos que los dejen vagar) (17).

Faltas contra la policía de la libertad (reuniones sin autorización y apertura de toda clase de establecimientos sin licencia) (18).

Faltas contra la policía de la moralidad (prostitución, juegos de azar, baños contra las reglas de docencia) (19).

Faltas de tráfico rodado y caballar (infracciones de reglamentos por carruajes públicos y los que corrieren carruajes o caballerías por lugares públicos con peligro de personas o infracción de ordenanzas) (20).

Faltas en materia de espectáculos (infracciones de organizadores y público) (21).

Faltas contra la policia de la salubridad (farmacéuticos y confiteros que den sustancias en mal estado, infracciones reglamentarias en momentos de epidemias o epizootias, conducciones y enterramientos irregulares de cadáveres, arrojar sustancias fétidas o insalubres $\mathrm{y}$ animales muertos a fuentes y lugares donde trastornen la higiene pública) (22).

Faltas en materia de protección urbanística, ambiental e industrial (descuidar los edificios ruinosos, negligencia en la elaboración y custodia de materias inflamables y corrosivas o en la apertura de pozos y excavaciones, no revisión de calderas, fuegos, hornos y estufas) (23).

(16) Artículo $592 \mathrm{CP}$ de 1870

(17) Artículos 600 y $599 \mathrm{CP}$ de 1870

(18) Artículo $594 \mathrm{CP}$ de 1870

(19) Artículo $596 \mathrm{CP}$ de 1870. Los juegos de azar no serían despenalizados hasta la publicación del Real Decreto-ley de 25 de febrero de 1977.

(20) Artículo $599 \mathrm{CP}$ de 1870

(21) Artículo $597 \mathrm{CP}$ de 1870

(22) Artículos 595 y $596 \mathrm{CP}$ de 1870

(23) Artículos 599 y $601 \mathrm{CP}$ de 1870 
Al lado de estas figuras plenamente relacionadas con las atribuciones de las Administraciones (en especial de la Municipal), nos hallamos, dentro de la misma rúbrica del Código Penal de 1870, con tipos difícilmente encasillables en la esfera de las policías administrativas que, al cabo, es la correcta traducción del «régimen de poblaciones»: Entre estos supuestos atípicos podemos encontrar al facultativo que silencia la presencia de veneno o indicios de otro delito en un cadáver (24), la llamada profanación leve de sepulturas (25), la negativa a recibir moneda legítima, y los que habiendo recibido de buena fe moneda o efectos falsos los transmitan constándoles ya la falsedad (26).

Centrándonos en los ilícitos contra el régimen de poblaciones, debemos recordar que muchos de los mismos, bajo el único título de faltas graves, figuraban ya en el Código Penal de 19 de marzo de 1848, que dedicaba sus artículos 471 y 472 , mayoritariamente, a este tipo de incumplimientos relacionados con la vida local (27). También incluía el meritado texto de 1848 otros comportamientos, como el de «los que apedrearen, mancharen o deterioraren estatuas, pinturas u otros monumentos de ornato o de utilidad pública, aunque pertenezcan a particulares», o el de "los que excitaren o dirigieren cencerradas o reuniones tumultuosas en ofensa de alguna persona o del sosiego de las poblaciones» (28). Estos dos tipos también mantienen una clara vinculación con la acción municipal; por cierto, el primero de ellos, el relativo a los daños leves a bienes de utilidad pública, fue recogido en el Código de 1870 como falta contra el orden público (29). El Código Penal de 1928 cambiará su incardinación manteniéndose hasta hoy en día dentro del cuadro de faltas contra el régimen de poblaciones (30).

Las sanciones que el Código de 1870 prescribía en vía judicial para los ilícitos que nos ocupan consistían en multas cuya cuantía oscilaba entre 5 y 75 pesetas, no pasando, en su mayoría, de los 10 duros, cantidad, por otra parte, con la que se permitía sancionar a los Alcaldes las infracciones de ordenanzas y reglamentos. En efecto, la Ley Municipal de 20 de agosto de 1870 autorizaba a los regidores de municipios capitales de provincia a imponer "penas».

(24) Artículo $595 \mathrm{CP}$ de 1870

(25) Artículo $596 \mathrm{CP}$ de 1870.

(26) Artículo $592 \mathrm{CP}$ de 1870.

(27) En los referidos artículos del Código de 1848 se encuentra la mayoria de las más tarde denominadas "faltas contra el régimen de las poblaciones», junto a otras conductas de más dificil encasillamiento como la "ofensa al poder con acciones deshonestas», intrusismo, uso indebido de condecoraciones, lesiones y daños leves, amenazas con arrepentimiento, denegación de auxilio, etc.

(28) Artículo 471, números 3 y 16, CP de 1848

(29) Artículo $585 \mathrm{CP}$ de 1870.

(30) Artículo $803 \mathrm{CP}$ de 1928.

REVISTA DE ESTUDIOS.-2 
de hasta 50 pesetas; a los de capitales de partido y poblaciones de más de 4.000 almas, hasta $25, y$, en los demás casos, el tope se hallaba en las 15 pesetas.

Si relacionamos los artículos 67.2 y 68 (relativos a competencias municipales) con los preceptos de la misma Ley Municipal de 1870, destinados a declarar las facultades castigadoras de los Alcaldes (72 y 107), veremos que casi todas las conductas insertas en el Código Penal como "faltas contra el régimen de poblaciones» podían ser reprendidas por aquéllos y con cantidades prácticamente idénticas. Por ello no es de extrañar la cautela del artículo 625 del Código Penal de 1870 (idéntico al vigente 603) que prohibía en lo sucesivo que disposiciones administrativas establecieran penas mayores a las fijadas para las faltas por el código punitivo, con expresa excepción de lo que dispongan leyes especiales. $Y$ en tal sentido la Ley Municipal (diez días anterior al Código) tenía dicho rango y singularidad. Pero, como es bien sabido, este es un problema que aún se mantiene en el presente, con la importante adición de que la Administración puede sancionar con cuantías muy superiores a las que fija la Ley Penal, no ya para las faltas, sino también para los delitos (31).

El Código Penal dictado bajo el mandato de Primo de Rivera, el 8 de septiembre de 1928, mantuvo en su muy prolijo y aumentado articulado la rúbrica que nos ocupa. Entre estas faltas contra el régimen de las poblaciones, como ya indicamos, el texto de 1928 insertó los daños leves a elementos de utilidad pública (art. 803) y tipificó como falta el hecho de vagabundear sin oficio ni beneficio, así como la utilización sin licencia de redes radiotelegráficas o radiotelefónicas, conducta esta última ciertamente preocupante para un Estado cimentado en la autoridad y la policía.

El advenimiento de la II República supuso el establecimiento del Código de 1870 (32) reformado mediante Ley de Bases de 8 de septiembre y Ley de 27 de octubre de 1932, que, en lo tocante a

(31) Este problema de la mayor sanción administrativa que penal demuestra la más fácil actualización de las normas administrativas en temas de cuantías, que tradicionalmente han estado deslegalizados. Hoy en día, no cabe duda de que una sanción gubernativa en materia alimentaria, urbanística o ambiental no puede ser parangonada, ni de lejos, por una multa penal. Como la batalla por mantener a ultranza la regla prioritaria del artículo 603 del Código Penal en favor de la consideración criminal está perdida de antemano, lo más sensato parece eliminar la duplicidad de tipos: En tal sentido la reforma de 1989 merece todos los parabienes pues simplifica en delitos e infracciones administrativas la mayoría de las cuestiones referidas a la vida local. Este viejo problema arranca, como hemos visto ya (por ejemplo al analizar el Decreto de 18 de mayo de 1853), de que hasta bien entrado este siglo no se habla de delitos, faltas e infracciones administrativas, sino de delitos $y$ faltas. $Y$ algunas de estas últimas eran susceptibles de sanción penal o gubernativa. La posible duplicidad sancionatoria es consustancial a los orígenes de la cuestión, tal vez por el papel preeminente, en estos temas, de los Alcaldes que en sus orígenes también fueron órganos jurisdiccionales.

(32) Recordemos que el Decreto-ley de 15 de abril de 1931 ordenó la revisión de toda la obra legislativa de la Dictadura de Primo de Rivera. 
los ilícitos objeto de este estudio, se limitó en sus artículos 568 a 576 a actualizar las cuantías de las penas fijadas en el cuerpo revolucionario (hasta 250 pesetas de multa como máximo), pero manteniendo, con respecto al texto original, la ubicación que el Código de la Dictadura había dado a los daños leves a bienes de utilidad pública. Pero la II República, como se ha·señalado certeramente (33), no cambió el signo de la legislación administrativa sancionadora en aras de una nítida judicialización de las sanciones. La Ley de Defensa de la República, de 1931; La Ley de Orden Público, de 1933, y la legislación local de 1935 son claros exponentes del reforzamiento de la potestad sancionadora de la Administración. El mismo principio de unidad jurisdiccional quebrará con la singularidad procesal de la Ley de Vagos y Maleantes, de 4 de agosto de 1933. Dicha norma, reformada el 24 de enero de 1963, encontró su perpetuación en la aún próxima Ley de Peligrosidad Social de 4 de agosto de 1970; en dichas normas se tipificaba la conducta de homosexuales, vagos y proxenetas como merecedora, junto a otros motivos político-sociales, de medidas de seguridad. El ocaso de esta legislación no comenzará a vislumbrarse hasta la Ley de 26 de diciembre de 1978.

Tras la guerra civil, la versión de Código punitivo que nos deparó la Ley de 19 de julio de 1944, apenas varió la ya tradicional redacción del texto republicano en lo alusivo a las faltas contra el régimen de las poblaciones. No deja, por ello, de extrañarnos que, por la inercia de la pura transcripción, al Estado nacional-católico se le escapara el mantenimiento como ilícitos, en el artículo $577,2 .^{\circ}$, de las infracciones de reglamentos policiales en materia de prostitución. Ello implicaba que tales reglamentos organizadores existían y subsistían (34). La cuestión no pasó desapercibida en la reforma de

(33) Por Parada VÁzQUez op. loc. ult. cit.

(34) La referencia a normas de policia sanitaria sobre prostitución ya la encontramos en el Código Penal de 1848 (art. 471.9 ) y en su reforma de 1850 . Sin embargo, en aquel momento no existía reglamentación alguna de carácter general. Ante tal inseguridad jurídica -muy propia en esta materia- MARTÍNEZ ALCUBILLA en su benemérito Diccionario de la Administración Española (tomo VII, Madrid, 1984, voz «mancebía)), aún proponía al Gobierno que diese contenido a la remisión penal usando las facultades contenidas en el articulo 2 del Real Decreto de 22 de septiembre de 1848. Dicho precepto invitaba al Gobierno a elevar a las Cortes cuantas reformas y adiciones fueran necesarias para dar eficacia al Código Penal. La reglamentación de la prostitución no la hallaremos hasta las Reales Ordenes de 28 de septiembre de 1910, 13 de marzo de 1918 y 22 de abril de 1922, la primera de las cuales encomendaba el comercio carnal al control de un Servicio de Higiene dependiente de las Juntas de Sanidad municipales $y$ provinciales. Esta previsión no era novedosa, ya que por Real Orden de 4 de enero de 1889 se puso a cargo de los Ayuntamientos el "servicio de higiene sobre casas de mancebia», que más tarde (Real Orden de 6 de diciembre de 1892) pasó a depender de los gobernadores civiles ante «la falta de vigilancia y la insuficiencia de las atribuciones que la Ley Municipal (refundición de 1877) concede a los alcaldes). Pero la Real Orden de 28 de septiembre de 1910 también fijaba la edad minima para prostituirse (veinticinco años, salvo autorización de los representantes de la menor). la prohibición de vida en común de las meretrices, la reglamentación del ejercicio "por cuenta $y$ en casa propia" y el reconocimiento obligatorio y gratuito de las prostitutas y los 


\section{4 de enero de 1963 (Decreto 168/1963, que desarrolló la Ley $79 / 1961$, de 23 de diciembre), que suprimió la referencia a la prostitución. Para entonces ya había sido aprobado el Decreto-ley}

lugares de lenocinio por parte del Cuerpo de Médicos Higienistas. En esta disposición administrativa (art. 12) se estableció el sufragio parcial de la lucha antivenérea mediante el pago de los reconocimientos médicos que las dueñas de los lupanares debian ingresar en las cajas de las Juntas de Sanidad provinciales o municipales. Contra este «origen inconfesable de los fondos» se rebelará el Decreto republicano de 7 de abril de 1932 que, sin citarla expresamente, tal vez por desconocimiento del origen, viene a derogar la Real Orden de 1910. Las Cortes Constituyentes, previamente, ya habian tenido «el honor de hacer desaparecer» una medida gubernativa «tan bochornosa y denigrante, incluyendo en los Presupuestos del Estado la partida correspondiente que ha de sustituir a tan vergonzoso tributo». Pero la época republicana aún conocerá otra medida más drástica, aunque abocada al fracaso: la declaración de ilicitud de la prostitución. En efecto, el Decreto del Ministerio de Trabajo de 28 de junio de 1935, creyendo ahondar en la lucha antivenérea, suprimió «la reglamentación de la prostitución, el ejercicio de la cual no se reconoce en España a partir de este Decreto como medio lícito de vida». Esta tibia redacción, unida a que no se tocó para nada el Código Penal, devolvió las mancebías a la arbitraria situación tradicional de una nunca mejor llamada tolerancia administrativa que permitía, entonces como ahora, una flexibilidad de criterios en manos de la autoridad y una inseguridad para los implicados en el más viejo de los oficios difícilmente congruentes con un Estado de Derecho. Otro Decreto de 11 de julio de 1935 contenía escuetamente una determinación de los órganos sancionadores administrativos (los inspectores provinciales de Sanidad y, en caso de reincidencia, "las autoridades superiores»), pero remitiendo las cuantías de las multas a la legislación general y sin indicar prácticamente los comportamientos castigables. El régimen de Franco comenzará por derogar, mediante Decreto de 27 de marzo de 1941, la norma abolicionista de 1935, con lo que podría pensarse que reconocía nuevamente la reglamentación de la prostitución. Pero como quiera que la derogación de una norma no implica en sí la resurrección de las anteriores, lo que se produjo en 1941 fue la culminación del caos de tolerancia connatural a la historia de las mancebias. La exposición de motivos del Decreto de 1941 no podía, por otra parte, ser más injusto y estéril: «El aumento de la morbilidad por enfermedades venéreas, ocasionado principalmente a la causa de la relajación moral que se padeció en la zona roja y por la falta de la debida atención al problema por las sedicentes autoridades de la misma... obligan a tomar medidas y derogar... el Decreto de 28 de junio de 1935." La hipocresía es manifiesta, pues si bien es cierto que el cambio de costumbres y los avatares de la guerra no favorecieron la campaña antivenérea, no es menos cierto que la República (contra lo que después se dijo desde la doctrina neoimperial) suprimió la prostitución y la combatió (en batalla siempre perdida de antemano, pues es una lucha contra la biología y la economía de supervivencia), prohibiendo la expedición, exigencia y exhibición de carnés profesionlaes donde se indicaba el "estado de salud» en cuestión venérea. Otro Decreto de 6 de noviembre de 1941 creará unos singulares establecimientos para la regeneración de mujeres extraviadas, donde se podia ingresar mediante sanción administrativa privativa de libertad, que oscilaba entre seis meses y dos años de «estancia».

La inseguridad habia llegado a su cenit, ya que, de un lado, se había abrogado la prohibición del ejercicio carnal y, de otro, pese a que las prostitutas como tales no estaban recriminadas ni por el Código Penal qque sólo contempla la currupción de menores, el proxenetismo, etc., y que en materia de faltas sólo entendía punibles las infracciones de los reglamentos de policía sanitaria, entonces inexistentes) ni explícitamente por la Ley de Vagos y Maleantes de 4 de agosto de 1933 (que en un magnifico ejemplo de bis in idem también se ocupaba de los proxenetas), la autoridad gubernativa podía recluir a las citadas meretrices hasta dos años en establecimiento de regeneración. El Código Penal, no obstante, mantendrá como falta contra el régimen de las poblaciones la inobservancia de los reglamentos sobre prostitución hasta la reforma de 24 de enero de 1963, coherente con el Decreto-ley de 3 de marzo de 1956 que. al ordenar el cese de las casas de tolerancia, dejó toda facultad sancionadora en manos de la Administración. Esta disposición de 1956 resultó tan baldía (baste decir que está teóricamente vigente) como la republicana de 1935 o como la vieja Pragmática de Felipe IV, de 1623, que también ordenó el cierre de las mancebías. Para un examen más detallado de este tema puede consultarse nuestro trabajo «Notas sobre la reglamentación, prohibición y tolerancia administrativa de la prostitución», actualmente en prensa en la Revista Española de Derecho Administrativo. 
de 3 de marzo de 1956, que obligaba a las mancebías y casas de tolerancia a cesar en "su ilícito tráfico» en un plazo de tres meses, bajo apercibimiento de cierre y sanción gubernativa. Esta disposición, despenalizadora del ejercicio en sí de la prostitución, amén de ser presa del desuso (baste decir que no se halla formalmente derogada) confirió a las autoridades administrativas unas facultades sumamente genéricas por más que se tratara de encajarlas en las competencias sancionadoras de Gobernadores civiles y Alcaldes. Su carácter temporal, su rango y su abstracción nos parecen poco compatibles con el principio de legalidad en materia sancionadora $y$, sobre todo, con los principios de seguridad jurídica e interdicción de la arbitrariedad. Precisamente, la frivolidad a la hora de trasladar in toto la represión penal al mundo administrativo es uno de los puntos más recriminables de la reciente modificación del Código punitivo. $\mathrm{O}$ el legislador, que es siempre el mismo, prevé los tipos de infracciones administrativas y la oscilación sancionatoria, o la más caótica arbitrariedad está garantizada. Valga el citado ejemplo de la prostitución para comprender cómo se prodigan, indistintamente, bulas y ensañamientos cuando la incertidumbre de la acción y lo difuso de la competencia del órgano sancionador presiden el espíritu de la norma.

Volviendo al contenido del título II del libro III del Código Penal, debemos rer.ordar que hasta la reforma de 1989 se mantuvieron todos los demás tipos contra el régimen de poblaciones reiterados desde la redacción de 1870 -e incluso con precedentes en el de 1848- con dos excepciones: las faltas por promover o participar en juegos de azar (35) y por dejar vagar por la calle a los enajenados (36). En el primer caso, tras la despenalización del juego operada en 1977, parecía lógico abolir igualmente el precepto relativo a las faltas, y así se hizo por Ley Orgánica 8/1983, de 25 de junio. La misma Ley que, a la vista de las modernas terapias psiquiátricas y de los problemas jurídicos que suscitan los internamientos de los enajenados (37), optó también por eliminar del Código Penal la falta en la que incurrían los que daban suelta a los enfermos mentales. Dicha Ley Orgánica de 1983 también actualizó levísimamente la terminología de los artículos $573,4 .^{\circ}, 576,2 .^{\circ}$ y $577,2^{\circ}$; todos ellos alusivos, igualmente, a acciones u omisiones contra el régimen de los pueblos.

(35) El Código Penal de 1848 prohibía los juegos de envite o azar en caminos públicos, calles, plazas, ferias o sitios semejantes de reuniones (art. 471.2). La redacción del texto de 1870 se mantuvo prácticamente sin cambio alguno hasta la despenalización de 1983 .

(36) Artículo $599.1^{\circ} \mathrm{CP}$ de 1870.

(37) Cfr. COBREROS MENDAZONA E.: Los tratamientos sanitarios obligatorios $y$ el derecho a la salud (estudio sistemático de los ordenamientos italiano y español), Instituto Vasco de Administración Pública, Oñati, 1988, muy especialmente pp. 115 y ss. y 369 y ss. 


\section{FALTAS ADMINISTRATIVAS Y PENALES:}

\section{LA OCASION PERDIDA EN LA REFORMA DE 1989}

\section{Los criterios de la exposición de motivos}

La reforma del Código Penal operada por Ley Orgánica 3/1989, de 21 de junio, ha reducido a su mínima expresión el ya exiguo cuadro de faltas contra los intereses generales y el régimen de las poblaciones. En total ha suprimido tres artículos y aligerado otros cinco. Antes de entrar en los supuestos concretos que se han visto afectados, debemos recordar que la Exposición de Motivos de la Ley Orgánica dedica un sustancioso párrafo a motivar el cambio que nos ocupa:

«El título II rubricado "De las faltas contra los intereses generales y el régimen de las poblaciones", y compuesto hasta ahora de veintiocho infracciones, queda integrado únicamente por seis faltas. Era éste un título de heterogéneo contenido, donde convivían la celebración de espectáculos sin licencia y el bañarse indecentemente, por ejemplo. Las infracciones que se depenalizan son, pues, de muy diversa naturaleza. Unas, como es el caso tomado como ejemplo de la celebración de espectáculos sin los necesarios permisos, tiene suficiente tratamiento en la actividad sancionadora de las Administraciones; otras, como el caso del baño ofensivo de las reglas de decencia, son exponentes de la confusión entre moral y derecho plasmada en elementos valorativos incompatibles con la seguridad jurídica; $y$, en general, el conjunto de conductas que se despenalizan no tiene otro carácter que el técnicamente conocido como infracciones de policía. La posibilidad de que tales comportamientos, u otros de análoga entidad, sean sancionados mediante ordenanzas o bandos es perfectamente ajustable a las garantías constitucionales, en cuanto a los derechos personales, y a las competencias de las autoridades administrativas, desde la Administración central a los entes locales.»

En cuanto a las faltas que permanecen, la Exposición prosigue:

«Subsisten... la tradicional falta consistente en negarse a recibir en pago moneda legítima, la falta de comunicación a la autoridad por parte de un facultativo de las señales de envenenamiento $u$ otro delito en persona o cadáver que 
examinaran, la profanación de cadáveres y la suelta peligrosa de animales feroces, conductas todas que se estima deben continuar en el ámbito penal por el grado de afección que, siquiera potencialmente, representan para determinados bienes jurídicos.»

Esta Exposición es, por muchos motivos, susceptible de puntualizaciones críticas. En primer lugar, si, como venimos apuntando a lo largo de este trabajo, nos hallamos ante «un título de heterogéneo contenido», ahora que prácticamente no quedan ya faltas auténticamente atentatorias contra la vida local, ¿por qué no se ha cambiado la rúbrica? ¿Qué compromiso de inmutabilidad tiene el legislador de 1989 con un desacierto de 1870?

Pero, no siendo esto baladí, lo más preocupante es el grado de conocimiento que demuestra el legislador con respecto a la doctrina constitucional sobre la potestad sancionadora de la Administración. Decir, como se dice, lisa y llanamente, que las ordenanzas y bandos pueden tipificar, sin más, conductas a reprender por «las autoridades administrativas, desde la Administración central a los entes locales», es, sencillamente, un despropósito. En primer lugar, no anda muy versado en Derecho Administrativo un órgano constitucional que extiende las ordenanzas y bandos a entes públicos no locales, y, en segundo término, las Cortes Generales parecen ignorar el concepto indivisible de la Ley, sea penal, administrativa o de otro orden. De lo contrario no se explica la carencia de toda cita del principio de legalidad en materia sancionadora. Es cierto que nuestro Tribunal Constitucional ha señalado, con respecto a la reserva de Ley incluida en el artículo 25.1 de la Constitución («nadie puede ser condenado o sancionado por acciones $u$ omisiones que en el momento de producirse no constituyan delito, falta o infracción administrativa, según la legislación vigente en aquel momento»), que su alcance "no puede ser tan estricto en relación con la regulación de las infracciones y sanciones administrativas como por referencia a los tipos y sanciones penales». Pero también hay que tener en cuenta que la misma sentencia constitucional $(42 / 1987$, de 7 de abril), reiterando otras de 21 de enero de 1987 y 3 de octubre de 1983, señaló que, "en todo caso aquel precepto constitucional (el artículo 25.1, en relación con el 9.3 y el 25.3) determina la necesaria cobertura de la potestad sancionadora de la Administración en una norma de rango legal, habida cuenta del carácter excepcional que los poderes sancionatorios en manos de la Administración presentan». Y aún no resulta más chocante la remisión global de la Exposición de Motivos de la Ley Orgánica reformadora del Código Penal en favor 
de «ordenanzas y bandos» cuando el Tribunal Constitucional viene señalando que, fuera de las relaciones de sujeción especial, la reserva de Ley no excluye que las Leyes contengan remisiones a normas reglamentarias, «pero sí que tales remisiones hagan posible una regulación independiente y no claramente subordinada a la Ley» (sentencias 83/1984, de 24 de julio, y 42/1987, de 7 de abril). Esa remisión abstracta que hace el Código Penal a las ordenanzas y bandos de las distintas Administraciones parece, también, un cheque en blanco para la diversidad sancionatoria y, en tal sentido, conviene atender al razonamiento de PARADA VÁZOUEZ: «El principio de legalidad debe entenderse en todo caso como exigencia de Ley estatal previa... (incluidas) las sanciones administrativas, dado que el artículo 149.1.1. ${ }^{\circ}$ de la Constitución reserva al Estado la competencia exclusiva para la regulación de las condiciones básicas de todos los españoles en el ejercicio de los derechos y en el cumplimiento de los deberes constitucionales, igualdad que resultaría alterada si el mapa autonómico ofreciese un variopinto y desigual régimen sancionador» (38). En suma, el principio de cobertura legal de las sanciones administrativas «sólo exige regular por Ley formal una descripción genérica de las conductas sancionables y las clases y cuantías de las sanciones, pero con posibilidad de remitir a la potestad reglamentaria la descripción pormenorizada de las conductas ilícitas, es decir, la tipicidad» (39).

Esta interpretación, ratificada por otras decisiones más recientes del Tribunal Constitucional (sentencias 101/1988, de 8 de junio, y 29/1989, de 6 de febrero), parte de una «imperiosa necesidad de predeterminación normativa de las conductas ilícitas y de las sanciones correspondientes, aunque, en materia administrativa, el detalle sancionador pueda quedar encomendado al reglamento, "en cierto modo insuprimible». Pero aun en el supuesto de las relaciones de sujeción especial (funcionarios, soldados, presidiarios, estudiantes, contratistas...), «en el que la potestad sancionadora no es la expresión del ius puniendi genérico del Estado, sino manifestación de la capacidad propia de autoordenación» (sentencia constitucional 2/1987, de 21 de enero), incluso, repetimos, en este ámbito, "una sanción carente de toda base normativa legal devendría lesiva del derecho fundamental que reconoce el citado artículo 25.1" (sentencia constitucional $69 / 1989$, de 20 de abril).

Y esa modulación en tres peldaños (ilícito penal, infracción administrativa general y falta en relación de sujeción especial) de la reserva de Ley del artículo 25.1 de la Constitución, aunque

(38) PaRAda VÁzoUez: Derecho Administrativo..., cit., pp. 356 y s.

(39) Op. ult. cit., pp. 355 y s 
razonable, no deja de ser una construcción teórica del intérprete de la Ley fundamental, toda vez que la accidentada (40) expresión "según la legislación vigente» es, bajo ninguna duda gramatical, igualmente aplicable a delitos, faltas penales e infracciones administrativas.

En suma, el preámbulo a la reforma penal de 1989 nos parece sumamente frívolo en tan espinosa cuestión. Y más adelante nos referiremos a algún supuesto ilustrativo del peligro que encierran las alegrías despenalizadoras que, tras su loable propósito, encierran una dudosa y simple deslegalización en materias donde tal figura está proscrita.

La meritada reforma del Código Penal sí persigue, y ello es encomiable, aunque expresamente no se señale, la repetición sancionatoria, el bis in idem cuya prohibición no llegó a plasmarse literalmente en la norma suprema. Lo que ocurre es que, en ocasiones, de la dualidad castigadora vamos a pasar a la impunidad, al quedar despenalizadas las correspondientes figuras $y$ al no hallarse sustento legal alguno las correspondientes sanciones administrativas, ya que, en algún supuesto, la posibilidad de reprender administrativamente determinadas conductas se vinculaba al tipo penal específico en relación con la regla contenida en el artículo 603 del Cuerpo punitivo. Ahora, las «ordenanzas y demás reglamentos" administrativos pueden convertirse en disposiciones independientes en aquellos casos en que no exista una Ley especial. Y ello, obviamente, conculca la doctrina constitucional sobre la potestad sancionadora de las Administraciones.

Siguiendo con la Exposición de Motivos de la Ley Orgánica $3 / 1989$, de 21 de junio, en ella se afirma, no sin razón, que la despenalización de faltas del tenor de "bañarse indecentemente» obedece a un respeto a la seguridad jurídica, incompatible con la confusión entre criterios de moralidad y de derecho. Sin embargo, el preámbulo añade más adelante, con expresión omnicomprensiva, que «el conjunto de conductas que se despenalizan no tiene otro carácter que el técnicamente conocido como infracciones de policía». Es decir: el Código Penal no debe inmiscuirse en la delimitación de lo ético y lo jurídico, pero cualquier ordenanza municipal sí puede hacerlo con las consiguientes sanciones administrativas y pese al silencio que, como veremos, guarda en este punto el artículo 115 de la vigente Ley de Costas de 28 de julio de 1988. No deja de ser chocante que cada Ayuntamiento al

(40) Como es bien conocido, el senador L. MARTÍN-RETORTILLO logró en el paso del texto constitucional por la Cámara Alta la sustitución de la ambigua expresión "legislación vigente" por la más restringida y a la vez segura de «ley». Tan loable intento no fructificó en la última redacción. 
ordenar el aprovechamiento y la gestión de sus playas y lugares de baño pueda tipificar, con mil variaciones según el punto geográfico y el grado de puritanismo del Consistorio, actitudes y atuendos que la Ley formal no considera conveniente abordar para no caer en la inseguridad jurídica (41).

Por último, en lo tocante a esta discutible Exposición de Motivos, debe señalarse que, tras declarar la sola subsistencia de seis faltas contra el régimen de las poblaciones, las enumera -lo que es innecesario- $y$ se refiere sólo a cuatro -lo que es incongruente-, dejando de citar, por cierto, la única que tiene algo que ver con la rúbrica superviviente: Los daños leves a bienes de utilidad pública.

En fin, si la doctrina de nuestros Tribunales ha venido asimilando a la sanción administrativa las garantías de la punición penal (legalidad, tipicidad, irretroactividad en lo no favorable, non bis in idem, audiencia y defensión plena, presunción de inocencia $y$ derecho a no declarar contra sí mismo y a no declararse culpable) (42), no entendemos el menosprecio inconsciente que la reforma del Código Penal parece hacer al hipotético infractor de normas de policía, ni la generosa, pero incorrecta, presunción que parece otorgar a unas Administraciones que, lejos de ser todopoderosas en lo normativo, se hallan positivamente vinculadas a los dictados previos de la Ley formal.

\section{Supuestos despenalizados y tipos mantenidos}

Si bien brevemente, parece necesario detenerse por un momento en las conductas que se han despenalizado y en las que se han mantenido bajo la vetusta, pero cada vez más incorrecta, denominación de ufaltas contra los intereses generales y el régimen de las poblaciones».

(41) Aunque el artículo 115 de la vigente Ley de Costas otorga a los Ayuntamientos la facultad de explotación, directa o indirecta, de los servicios de temporada de las playas, así como el mantenimiento de las normas de seguridad y salvamento dictadas por el Estado y la limpieza y cuidado de las zonas, el artículo 34 de la misma Ley (sin perjuicio de las atribuciones autonómicas o municipales) otorga a la Administración central la potestad para dictar reglamentos-directrices en lo concerniente, entre otras materias, a «régimen de utilización de las playas, seguridad humana en los lugares de baño y demás condiciones generales sobre uso de aquéllas y sus instalaciones». La Ley, que en otros puntos es expresa (por ejemplo, al prohibir las playas privadas, art. 33.1), muestra un extraño silencio a la hora de permitir, o no, separaciones por motivos naturistas o de pudor, aunque tal cuestión entraría dentro del "régimen de utilización de las playas». Cuando estas directrices estatales son especificas para una zona geográfica se requiere el informe previo de la Comunidad Autónoma y de los Ayuntamientos implicados (art. 34.2 de la Ley de Costas).

(42) Cfr. PARAdA VÁzoUez: Derecho Administrativo..., cit., pp. 354 y ss. Sobre otro principio bien conocido, el de proporcionalidad, vid. TORNOS MAS J.: «Infracción y sanción administrativa: el tema de su proporcionalidad en la jurisprudencia contencioso-administrativa», REDA, núm. 7, 1975, pp. 607 y ss. 
En primer lugar, dentro del artículo 573 del Código Penal, se han derogado dos conductas defraudatorias del comercio: la posesión de medidas o pesos para defraudar y el tráfico de sustancias alimenticias cuyo peso, medida o calidad no se corresponda a la anunciada. La Administración, en efecto, viene poseyendo y ejercitando facultades (43) sancionatorias en materia industrial y sanitaria que permiten, siempre que se dé la debida cobertura legal, perseguir con más eficacia que la propia Administración de Justicia, los comportamientos recientemente despenalizados. $Y$, de otra parte, se evita, igual que en otras faltas, un posible bis in idem o, simplemente, la conculcación del artículo 603 del Código Penal al ser, habitualmente, las multas administrativas de superior cuantía a las del cuerpo punitivo. En este mismo grupo despenalizado debemos incluir las faltas en las que incurrían farmacéuticos y hosteleros por despachar sustancias adulteradas (art. $576 \mathrm{CP}$ ). Por otra parte, los comportamientos más graves siguen tipificados como delitos en los artículos 343,344 bis y 346 del Código, bajo la rúbrica "contra la salud pública». En suma, lo que se ha hecho es. reducir las acciones y omisiones a dos categorías -delitos e infracciones administrativas- por no tener razón de ser la categoría de falta penal que, en muchos casos, se solapaba con las otras dos. Siempre quedará, es cierto, el problema de discernir dónde se acaba lo criminal y empieza lo gubernativo, pero, al menos, los Tribunales (incluido el de Conflictos de Jurisdicción) sólo tendrán que examinar dos posibilidades y no tres.

En segundo lugar, también se han despenalizado los falsos rumores no graves tendentes a alterar el precio natural de las cosas y la infracción de reglas de policía que aseguran el abastecimiento

(43) Los municipios deben proceder, sin excepción, al control de alimentos y bebidas fart. $25.1, a)$, LBRL] y a la inherente sanción de la infracción de las ordenanzas en tal sentido [art. 21. 1, k), LBRL]. La Ley General de Sanidad extiende esta competencia a los demás productos de uso o consumo humano y a su transporte [art. 42.3, d)] LGS, en relación con los arts. 35 a 37 de la misma Ley. Este último precepto posibilita medidas de clausura o suspensión para los establecimientos que no cuenten con autorización o registro sanitario preceptivo. Dichas medidas, a diferencia del cierre temporal a que se refiere, para infracciones muy graves, el art. 36.2 de la Ley, carece de naturaleza sancionadora). PARADA VÁZQUEZ por su parte, nos recuerda (Derecho Administrativo..., cit., p. 339) que el Real Decreto de 22 de diciembre de 1908 fue la primera norma de defensa de los consumidores frente a los fraudes en las cantidades y calidades, conteniéndose en la misma una clara reserva sancionadora en manos de los Tribunales. La Administración instruye pero no reprime. En materia de Pesas y Medidas oficiales, véanse la Ley de 1892 (8 de julio), el Decreto de 1 de febrero de 1952 y. más modernamente, el Real Decreto 1945/1983, de 22 de junio, que regula las infracciones $y$ sanciones en materia de defensa del consumidor y de la producción agroalimentaria, y la Ley 26/1984, de 19 de julio, para la Defensa de los Consumidores y Usuarios.

En lo tocante a la protección administrativa frente a infracciones procedentes de la industria, recordemos lo dispuesto en los artículos 6, 38 y 39 del Reglamento de Actividades Molestas, Insalubres. Nocivas y Peligrosas (Decreto 2414/1961, de 30 de diciembre), en lo tocante a materias explosivas y a las sanciones de Alcaldes (multa, retirada temporal y retirada definitiva de la licencia) y Gobernadores civiles, por subrogación de los anteriores. 
de poblaciones (art. $574 \mathrm{CP}$ ). Naturalmente, lo que son meras medidas de policía deben quedar en manos de la Administración y, al igual que vimos más atrás, los comportamientos graves (y la gravedad aquí se detalla por el Código) se mantienen como delitos específicos (arts. 540 y $541 \mathrm{CP}$ ).

En tercer lugar, nos hallamos con despenalizaciones exclusivas del ámbito sanitario, casi siempre consideradas en el Código como inobservancia de reglamentos administrativos. Tal es el caso de la infracción de normas $u$ ordenanzas sobre epidemias, epizootias (Reglamento de 25 de abril de 1986), sustancias fétidas e insalubres o higiene pública, en general (art. $577 \mathrm{CP}$ ). Comentario aparte merece, dentro de este mismo orden de cosas, la destipificación de la infracción de «las disposiciones sanitarias dictadas por la Administración sobre conducción de cadáveres y enterramientos» (antiguo art. $577.4 .^{\circ} \mathrm{CP}$. Esta falta era sustancialmente idéntica al artículo 345, que, incluso, es menos amplio que el derogado, ya que tipifica como delitos la exhumación y traslado de restos, en tanto que la simple falta abarcaba también a las inhumaciones y primeras conducciones de cadáveres. Como ya resaltamos en otra ocasión (44), la confusión aún se incrementaba con el Reglamento de Policía Sanitaria Mortuoria, de 20 de julio de 1974, que otorgaba a los Gobernadores civiles la facultad de sancionar "con multa de hasta 100.000 pesetas» este tipo de conductas, "salvo que constituyan delitos o faltas sancionadas con arreglo al Código Penal, en cuyo caso las actuaciones practicadas se remitirán a la autoridad judicial» (adicional 2. ${ }^{\circ}$ del Reglamento). El Ministro de la Gobernación podía imponer sanciones de hasta 500.000 pesetas por faltas muy graves. Es decir, amén de existir una modulación de infracciones administrativas (aunque la norma sanitario-mortuoria no establecía gradación ni tipo alguno), nos encontrábamos la yuxtaposición de faltas y delitos por idénticas conductas. $Y$ dándose además la paradoja de que, aunque el texto de policía administrativa, en la línea del artículo 603 del Código Penal y del artículo $4 .^{\circ}$ de la Ley de la Jurisdicción Contencioso-Administrativa, obligaban a la Administración o a los Tribunales del citado orden a paralizar cualquier expediente sancionador si era delito o falta, lo cierto era que las facultades sancionadoras de la Administración resultaban muy superiores a las que podían imponer los órganos judiciales penales. De ahí lo sorprendente de que, cuando las más altas instancias de lo contencioso-administrativo se hallaran revisando una sanción ministerial de medio millón de pesetas, un juez de Paz podía paralizar todo lo actuado al considerar la conducta

(44) En nuestro libro Dogma y realidad del Derecho mortuorio español, Instituto de Estudios de Administración Local, Madrid, 1983, pp. 202 y ss. 
constitutiva de falta contra el régimen de las poblaciones y sancionable con quinientas pesetas.

Por último, en esta línea higienista, la reforma de 1989 también ha suprimido la falta consistente en arrojar animales muertos, basuras o escombros a lugares públicos o ensuciar fuentes y abrevaderos (art. 577.6. ${ }^{\circ} \mathrm{CP}$ ), por considerar que, entre las ordenanzas municipales y la tipificación delictual del artículo $347.2 .^{\circ}$ del Código Penal, estaba ya suficientemente tutelado el bien jurídico de la salud pública (45).

En cuarto término, también se ha despenalizado el hecho de bañarse «faltando a las reglas de decencia o de seguridad establecidas por la autoridad». Conforme al principio de legalidad penal, al no caber ninguna pena sin norma tipificadora previa, habría que entender que todas las Administraciones tenían una regulación de decencia y seguridad en el baño, lo que no es, ciertamente, muy exacto. Además, la normativa local (46) y de costas -artículo 115 de la Ley- siguen sin prever atribuciones muy concretas en lo tocante al decoro (no así a la seguridad), por lo que, como hemos señalado más atrás, cualquier reglamentación municipal en la materia sería prácticamente independiente de toda Ley. $Y$ el problema existe con el acotamiento de espacios reservados para el desnudismo. Es éste un problema similar al de la despenalización de determinados supuestos de escándalo público (47). No debe dejarse en manos de la Administración un juicio de moralidad que el Legislativo rehúye y que los Tribunales prefieren eludir. Pero lo cierto es que sí existen múltiples ordenanzas de baños públicos sin cobertura legal alguna en lo sancionador. Y si bien la condición de

(45) Amén de lo dispuesto en la LBRL y en la LGS sobre higiene pública, residuos, basuras y contaminación de aguas, véase la Ley 42/1975, de 19 de noviembre (modificada por Real Decreto legislativo de 13 de junio de 1986) sobre recogida y tratamiento de desechos y residuos sólidos urbanos.

(46) La legislación local no hace previsiones especiales para los municipios costeros, sino que se refiere a conceptos generales como "salubridad pública», «seguridad en lugares públicos", "protección del medio ambiente», etc. Dado el carácter estatal de las costas, es lógico que las previsiones sobre competencias municipales en la materia vengan dadas por la normativa del Estado sobre demanio marítimo. Es más: mientras las casas de baños y piscinas son susceptibles de tasas por prestación de servicios (art. 212.16 del texto refundido de Régimen Local), las playas no aparecen recogidas por su carácter de bienes de uso común general (art. 31.1 de la Ley de Costas). Pero la Ley local tampoco prohibe expresamente las tasas en esta materia, por excederle la competencia. Tanto la Ley de Costas como el texto refundido de Régimen Local si permiten la utilización de suelo público por mesas, sillas y otros elementos, propios también de los servicios de temporada que, ya lo hemos dicho, pueden explotarse directa o indirectamente por los Ayuntamientos, dando lugar aqui a la presencia de eventuales concesionarios. Véanse también, en esta línea, los articulos 20 (tasas) y 41 (precios públicos) de la Ley 39/1988, de 28 de diciembre, de Haciendas Locales.

(47) La reforma de los artículos 431 y 432 del Código Penal, operada por Ley Orgánica $5 / 1988$, de 5 de junio, ha aminorado el riesgo de inseguridad juridica en lo que antes era "escándalo público". y ahora son actos "lúbricos u obscenos» de exhibicionismo y provocación sexual. Pero la indeterminación de conceptos y su carga moral no siempre conducirán a interpretaciones univocas. 
usuario de un servicio municipal (una piscina) podría considerarse un supuesto más de sujeción especial, sometido a una mayor laxitud sancionadora, según el Tribunal Constitucional, la utilización de un bien demanial de uso general, como una playa (48), no parece admitir tanta libertad en el castigo administrativo, dado el silencio sancionador del artículo 34, e, de la vigente Ley de Costas (49).

Como quinto grupo despenalizado nos encontramos con las faltas en materia de policía de libertad atinentes a espectáculos (50) y reuniones no autorizadas o extralimitadas y a la apertura sin licencia de cualquier tipo de establecimientos (art. 578 CP). La despenalización aquí parece lógica, ya que la normativa sobre derechos debe y puede -dado su rango- prever las limitaciones y sanciones al ejercicio incorrecto de aquéllos (51) que, tradicionalmente, ha de quedar en manos de la autoridad de policía, sin perjuicio de una eficaz tutela judicial frente a dichas actuaciones administrativas.

Por último, han pasado a mejor vida criminal un conjunto de faltas en materia urbanístico-ambiental, como verter aguas o piedras a las calles, mantener en las fachadas objetos que supongan riesgo a los viandantes, no reparar edificios ruinosos, infringir

(48) Vid. artículo 31,1 de la Ley de Costas. Esta calificación, en la doctrina, puede hallarse en PAREJo GamiR y RODRiguez Oliver: Lecciones de dominio público, ICAI, Madrid, 1975, p. 162. El "en todo caso» que el artículo 132.2 de la Constitución predica del carácter público de las playas lo repite el artículo 31.1 de la Ley de Costas a efectos de bañarse, pasear, estar, etc. La concesión demanial está circunscrita a los supuestos previstos en los artículos 31.2 y 32 de la citada Ley (rentabilidad, imposibilidad de otra ubicación, etc.). En ningún caso debe confundirse esta hipotética concesión demanial con las formas de gestión indirecta de los servicios de temporada que, en ningún caso, podrán exceder en superficie, sumando todo tipo de instalaciones, la mitad de la playa en pleamar (art. 33.4 Ley de Costas). También son distinguibles las autorizaciones de servicios de temporada que sólo impliquen instalaciones desmontables o muebles y que pueden ser otorgadas a los Ayuntamientos que lo soliciten para su posterior gestión (art. 53 de la Ley de Costas)

(49) Dicho precepto sólo contempla la «utilización de las playas, seguridad humana en los lugares de baño y demás condiciones generales sobre uso de aquéllas y sus instalaciones». Las sanciones se recogen en los artículos 94 y siguientes de la Ley que prevé la concurrencia de delito e infracción administrativa en materia de costas, obligando a la Administración a abstenerse de proseguir cualquier procedimiento sancionador en tanto no se dicte sentencia penal y excluyendo la duplicidad sancionadora (art. 94). También se prevé, amén de la típica multa, la restitución y reposición (o de ser imposible la indemnización) de los daños y perjuicios causados.

(50) Se ha dejado sin contenido el artículo 578 del Código Penal. La Ley de Orden Público de 30 de julio de 1959 ya preveía en su artículo 2, el, sanciones gubernativas en la materia. El tema actualmente debe ser contemplado desde la óptica "despolitizada» del Reglamento de Policía de Espectáculos, aprobado por Real Decreto 2816/1982, de 27 de agosto.

(51) La Ley orgánica 9/1983, de 15 de julio, reguladora del derecho de reunión, aunque permite la compulsión física sobre las personas (art. 5 de la Ley Orgánica, en relación con el 104, de la Ley de Procedimiento Administrativo), no prevé medidas sancionadoras, por lo que éstas deben buscarse (al margen de la responsabilidad civil, art. 4.3 de la Ley Orgánica) en la normativa de orden público y en el propio Estatuto de Gobernadores Civiles (Real Decreto 3117/1980, de 22 de diciembre) en sus artículos 15 y 17, e). Al respecto, también pueden consultarse el Decreto $1704 / 1965$, de 16 de junio, sobre vigencia del procedimiento sancionador gubernativo y el Real Decreto $831 / 1981$, de 10 de abril, sobre actualización de cuantías en las multas. 
ordenanzas en materia de fuegos y humos, pozos y excavaciones o materias inflamables o corrosivas (arts. 580 y $581 \mathrm{CP}$ ). Todas estas conductas pueden ser correctamente recriminadas desde normas municipales vinculadas a leyes formales (52), sin que su sanción, como ya se ha señalado más atrás, deba ser necesariamente pecuniaria (53).

Por el contrario, las conductas que se han mantenido como faltas en la reforma de 1989 pertenecen, en su mayoría, a intereses ajenos a los peculiares de los pueblos; por ello, al haberse acentuado aún más el carácter de «cajón de sastre» del título $\|$ del libro III del Código Penal, nos resulta incomprensible la fidelidad del actual legislador a la denominación, ya desafortunada, de 1870 .

En efecto, subsisten como faltas contra los intereses generales y el régimen de las poblaciones, desde falsedades menores o negativas a aceptar moneda legal (art. 573 CP) hasta el silencio del facultativo que observa indicios de delito en un cadáver (art. $576 \mathrm{CP}$ ), pasando por la macabra sutileza de la profanación leve de cadáveres y sepulturas (art. $577 \mathrm{CP}$ ). Esta última figura sí que hubiera merecido la pena que el Parlamento la reconsiderara, ya que es un foco de inseguridad jurídica con respecto al delito de profanación (art. $340 \mathrm{CP}$ ) que se configura de forma casi idéntica desde una intangible protección «a la memoria de los muertos» violentada por el forzamiento de tumbas o «cualesquiera actos de profanación de cadáveres». Si el delito abarca «cualesquiera actos» ¿cómo puede el órgano judicial discernir lo que es una profanación leve reprensible como mera falta? La invitación a disquisiciones de un necrófilo bizantinismo está servida (54). Pero, además, la falta en cuestión también pudo ser eliminada, ya que lo que realmente son daños leves en los cementerios no suponen otra cosa que daños al demanio municipal, dado el carácter, al fin inequívoco, de las necrópolis, que son bienes públicos afectos a un servicio mínimo (55). Por tanto, entre la protección penal dispensada al

(52) La normativa aplicable al respecto es muy variada en tiempo, materia y rango. Una vez más se echa en falta la imperiosa necesidad de una ley general y básica común a todos los procedimientos sancionadores de las diversas Administraciones, ley que ha sido reclamada, como ya vimos, por la doctrina más autorizada. En materia de edificios ruinosos puede verse lo dispuesto por el artículo 28 y concordantes del Reglamento de Disciplina Urbanística de 23 de junio de 1978, que destina, «sin perjuicio de las responsabilidades penales», sus artículos 51 y siguientes a las infracciones y sanciones urbanísticas. Recordemos también lo dispuesto en el Reglamento de Actividades Clasificadas de 1961 (arts. 38 y ss.) y la propia habilitación sancionadora del incumplimiento de ordenanzas, contenida en el artículo 21,1 , k), de la LBRL.

(53) Puede consistir en la suspensión o cese de una actividad, en la obligación accesoria de reparar lo dañado, etc.

(54) Vid. nuestro trabajo citado en nota número 44.

(55) El carácter de servicio público de los cementerios, defendido por FERNÁNDEZ DE VELASCO fue admitido con tibieza en la normativa local de los años cincuenta. Hoy, los artículos 26 y 86.3 de la LBRL no dejan lugar a dudas sobre tal consideración. Véase nuestro trabajo "Los servicios mortuorios locales: cementerios y servicios funerarios», en la obra colectiva Tratado 
demanio y las sanciones administrativas de defensa de bienes $y$ servicios era ya más que suficiente y se evitaba, de paso, la confusión entre las dos categorías criminales.

Precisamente los daños leves a bienes de utilidad pública, ornato o recreo, "aun cuando pertenecieren a particulares», es prácticamente la única falta que auténticamente atenta contra la vida local y sus intereses y que se ha mantenido en la reforma de 1989 (art. 579 CP). Este precepto que tipifica el apedrear, manchar o dañar de otro modo leve estatuas, pinturas, viales, jardines, alumbrado y otros elementos útiles o estéticos, es el modo menor del delito tipificado en el artículo 561 del Cuerpo punitivo y de otros preceptos incriminatorios de daños contra el demanio esparcidos sin orden ni concierto por un Código ajeno a la realidad administrativa (56). Procede dicha falta, como ya hemos señalado, del Código de 1848 (art. 471.3), fue considerada por el Código de 1870 como falta contra el orden público $y$, por fin, incluida en la rúbrica actual por el cuerpo legal de 1928 (art. 803). La pena que merece tal conducta es, en la actualidad, la de arresto menor y multa de 5.000 a 50.000 pesetas.

También, por último, la reforma penal de 1989 ha declarado subsistente la responsabilidad de los dueños o encargados de animales feroces o dañinos que los dejaren sueltos o en disposición de causar mal. Tal supuesto, que tampoco es ajeno a la reglamentación administrativa (57), debe presuponer un dolo o negligencia grave, amén del carácter agresivo del animal (potencialmente todos pueden serlo), ya que, de lo contrario, la mera responsabilidad extracontractual del artículo 1.905 del Código Civil estaría de más. El vigente precepto del Código Penal (el núm. 580) procede y es pura transcripción del artículo 599 del Código de 1870 . Su pena es la sola multa entre 5.000 y 25.000 pesetas.

de Derecho Municipal, (dirigida por S MUÑOZ MACHADO), vol. Il, Civitas, Madrid, 1988, pp. 1571 y ss. Sobre sanciones en materia de cementerios véase, amén de lo dispuesto en el Reglamento Estatal de Sanidad Mortuoria de 20 de julio de 1974, lo establecido en el artículo 10 del Decreto de la Generalidad de Cataluña 42/1981, de 16 de febrero, y los articulos 30 y 31 del Decreto de la Xunta de Galicia 133/1982, de 4 de noviembre, ambos sobre cementerios públicos de la Comunidad.

(56) Asi, el articulo $554 \mathrm{CP}$ se refiere a los daños y estragos en los carriles férreos, aeronaves o telégrafos; el $561 \mathrm{CP}$ contempla la destrucción de monumentos públicos, pinturas o elementos de ornato; el 558, los daños a puentes, caminos, paseos u otros bienes de uso público o comunal o en el Patrimonio Histórico, etc. Sería necesaria una contemplación común de los bienes públicos, sin perjuicio del agravamiento de conductas en función de la magnitud social del daño.

(57) Tanto desde el punto de vista de la legislación de caza como desde la reglamentación de animales domésticos, que pueden volverse dañinos (ver Orden de Gobernación de 14 de junio de 1976). 


\section{APELACION A UN CAMBIO REAL E INAPLAZABLE}

A título de reflexión final, no podemos por menos que sorprendernos del mantenimiento a ultranza por el legislador de los compartimentos estancos del Derecho. Parece inaceptable, ante la inequivoca unidad del ordenamiento, que el Parlamento cuando acomete la modificación de un tema penal se olvide de los demás órdenes limítrofes. Como también es injustificable la frivolidad con que se deja en manos de una decimonónica función de policía la posibilidad de prever actos de gravamen sobre los particulares. Por atenuado que se hallase el principio de legalidad en materia de sanciones administrativas, parece poco rigurosa y auspiciable la remisión en blanco a "bandos y ordenanzas» que realiza el Cuerpo punitivo a la hora de despenalizar determinadas acciones u omisiones. Remisión al derecho administrativo que deviene sumamente peligrosa al faltar una ley general que establezca los principios generales de la potestad sancionadora en las diversas materias y para las distintas Administraciones.

En concreto, la reforma penal de 21 de junio de 1989 ha mantenido con un sentimentalismo digno de mejor causa la rúbrica del título II del libro III del Código, cuando prácticamente ha barrido del mismo cualquier falta contra los intereses de los pueblos. La lógica concordancia entre el nombre del continente y el fondo del contenido ha brillado por su ausencia. Algunas de las supresiones realizadas y el propio espíritu despenalizador han sido encomiables, reduciendo la inseguridad calificadora existente hasta la actualidad. Pero, en otros muchos casos, se ha dejado al albur de la Administración $-y$ ¿cuál de ellas?, por cierto- el sancionar conductas no siempre bien configuradas por la «legislación vigente» $y$, en ocasiones, de espinosas aristas en su tipificación. Podría decirse que con la reforma que hemos comentado han disminuido el riesgo del bis in idem y la ineficacia de la cláusula de prevalencia penal del artículo 603 del Código criminal, pero ha aumentado la inseguridad jurídica en aquellas materias ahora reservadas a la acción sancionadora administrativa, donde las leyes especiales son escuetas, oscuras, arcaicas o simplemente ajenas a las medidas castigadoras.

Por último, en la línea de cuanto venimos apuntando, parecería necesario que una futura ordenación penal partiera, en lo tocante al mundo administrativo, de una mejor sistemática, pues es mucho lo que ha llovido en el Derecho público desde la Revolución de septiembre de 1868 sin que el legislador de lo criminal parezca haberse apercibido desde su opaca contemplación de la realidad. 
Lo deslabazado de la consideración del dominio público por parte de un texto heredero de una concepción aún anterior al artículo 338 del Código Civil y la caótica dispersión de los preceptos relacionados con esta materia sólo es comparable a la dualidad de nociones (penal-administrativa) sobre la función pública (58) o al desorden con que la propia norma punitiva amenaza a los funcionarios por doquier. La misma consideración de los delitos contra la seguridad del Estado y sus autoridades merecerían una revisión total de dimensiones y perspectivas bien distintas a los actuales apuntalamientos y enjalbergaduras que, en buena lógica, no detendrán la ruina interior de un venerable Cuerpo legal que, en sustancia, puede jactarse de haber sobrevivido a seis cambios políticos, pero, eso sí, sin percatarse de cuanto en política ha habido de cambio.

(58) Véase el concepto objetivo de funcionario (en atención a las funciones que se ejercen, bien por disposición inmediata de la ley, bien por elección o por nombramiento de autoridad competente), que define el artículo 119 del vigente Código Penal. Tan amplia y desfasada concepción ha sido aún ensanchada por la jurisprudencia de la Sala Segunda del Tribunal Supremo, que ha reconocido, por ejemplo, carácter funcionarial a los empleados de notaría (sentencia de 28 de febrero de 1974). 